\title{
Lung Cancer Related Central Airway Obstruction: Who Benefits Better from Radiotherapy?
}

\author{
Yurday OZDEMIR, Berna A. YILDIRIM, Erkan TOPKAN \\ Baskent University Adana Treatment and Research Center, Department of Radiation Oncology, Adana, TURKEY
}

\begin{abstract}
We aimed to assess the efficacy of external beam radiotherapy (EBRT) in central airway obstruction (CAO) and associated factors for metastatic lung cancer (MLC) patients. Records of $72 \mathrm{MLC}$ patients presenting with CAO were retrospectively analyzed. The serial chests X-rays prior and after the EBRT were compared for response assessment. The primary end-point was radiologic response, while overall- (OS) and CAO-free survival, and predictors of better outcomes constituted secondary endpoints. The EBRT doses ranged between 8 to 40 Gy (1-13 fractions). Median follow-up and OS were 5.6 (range: 1.3-17.8) and 7.6 months (95\% Cl: 6.5-8.7), respectively. Objective CAO resolution was achieved in 58 patients $(80.6 \%)$ on serial chest X-rays with a median time to maximum CAO response of 23 days (range: $3-86$ ). In responders the response was durable ( 8.1 months) almost nearly for all their remaining life spans (8.3 months) with only 19.0\% CAO recurrences. Median OS was also significantly longer in responders (8.3 vs. 2.4 months; $p<$ 0.001 ). Small-cell histology ( $p=0.002)$, tumor size $<5.3 \mathrm{~cm}$ ( $p=0.007$ ), and biologically equivalent dose (BED10) $\geq 39$ Gy $(p<0.001)$ were associated with better CAO response, while the presence of CAO response $(p<0.001)$ and BED10 $\geq 39$ Gy $(p=0.008)$ were the factors to relate with better OS on multivariate analyses. The EBRT proves effective and durable CAO palliation with only 19.0\% re-CAO rate in MLC patients. Better CAO responses may be achieved in patients treated with smaller tumor size, small-cell histology, and higher BED10 values.
\end{abstract}

Keywords: Central airway obstruction, Metastatic lung cancer, External beam radiotherapy

\section{ÖZET}

Akciğer Kanseri İlişkili Santral Hava Yolu Tıkanıklığı: Radyoterapiden Kim Daha Fazla Fayda Görür?

Metastatik akciğer kanserine (MAK) bağlı gelişen santral hava yolu tıkanıklığının (SHT) palyatif tedavisinde radyoterapinin (RT) etkinliği ve etkinlikle ilişkili faktörlerin araştıııması amaçlanmıştır. Bu amaçla 72 hasta geriye dönük olarak incelenmiştir. RT'ye cevap değerlendirmesi seri akciğer grafileri (SAG) kullanılarak yapılmışıı. Primer sonlanım noktası radyolojik cevap; ikincil sonlanım noktaları genel sağ kalım (GS), SHT'siz sağ kalım ve daha iyi sonuç göstergelerinin araştıııması olarak belirlenmiştir. RT dozları 8-40 Gy'dir (1-13 fraksiyon). Ortanca takip süresi ve GS sırasıyla 5.6 (aralık: 1.3-17.8) ve 7.6 (95\% Cl: 6.5-8.7) aydır. SAG ile takipte 58 (\%80.6) hastada objektif yanıt elde edilmiş olup SHT'deki maksimum düzelme ortanca 23 günde (3-86) gerçekleşmiştir. RT'ye yanıt veren hastalardaki ortanca 8.3 aylık GS süresinin 8.1 ayında amaçlanan palyasyon sağlanırken; hastaların \%19'da SHT tekrarlamıştır. Ortanca GS süresi RT'ye yanıt veren (8.3 karşın 2,4 ay; $p<0.001$ ) hastalarda daha yüksek bulunmuştur. Küçük hücreli histoloji ( $p=0.002)$, tümör boyutunun $<5.3 \mathrm{~cm}(p=0.007)$ ve biyolojik eşdeğer dozun $\geq 39$ Gy ( $p<0.001)$ olması RT sonrası SHT'de daha iyi yanıtla ilişkili bulunurken; çok değişkenli analizlerde RT'ye yanıt ( $p<0.001)$ ve BED10 $\geq 39$ Gy $(p=0.008)$ daha uzun GS ile ilişkili bulunmuştur. RT ile MAK'da gelişen SHT'de etkin ve uzun süreli palyasyon sağlanmıştır (sadece \%19'luk SHT'de tekrarlama). Tümör boyutu küçük olan, küçük hücreli alt histolojiye sahip ve yüksek doz RT uygulanan (BED10) hastalarda SHT'de daha iyi sonuçlar elde edilebilir.

Anahtar Kelimeler: Santral hava yolu tıkanıklığı, Metastatik akciğer kanseri, Eksternal beam radyoterapi 


\section{INTRODUCTION}

Central airway obstruction (CAO), defined as obstruction of the lumen or air flow at the level of trachea, main carina and main bronchi due to intra- or extraluminal disease is one of the major complications of locally advanced- and metastatic lung cancer (MLC) which deteriorates patients' quality of life (QoL) measures and survival outcomes. CAO may develop in nearly up to $30 \%$ lung cancer patients either at the early phases or later anywhere during the disease course. ${ }^{1,2}$

Although the well-established initial management of MLC constitutes systemic chemotherapy, yet persistent symptoms related with CAO may mandate the urgent use of invasive or/and non-invasive interventions against primary obstructive area as the initial step of treatment. ${ }^{3,4}$ In these situations, the commonly utilized treatment modalities involve the stent placement, dilatation, endoscopic laser ablation (ELA), argon plasma coagulation (APC), photodynamic therapy (PDT), endobronchial brachytherapy (EBB) and external beam radiotherapy (EBRT).$^{5-7}$ In general, ELA, APC, PDT, and EBB are implemented for the treatment of intraluminal tumors, while stent placement is usually reserved mainly for the obstructions caused by extraluminal masses with/without intraluminal extensions. ${ }^{8}$ Aside the technical difficulties in their use, almost each of these modalities has the potential to cause severe complications; such as, fatal hemorrhage and lower respiratory tract infections for airway stents ${ }^{9-12}$ or tracheobronchitis, hemoptysis, tracheomalacia and bronchial stenosis for $\mathrm{EBB}^{8}$, which frequently precluding their use as the first maneuver for CAO palliation. These severe complications may underlie the obvious need for alternative noninvasive but efficient treatment modalities with minimal toxicity profiles.

Considering its well-recognized tumor downsizing and palliative efficacy irrespective of the tumor's relation with bronchial lumen, together with its noninvasive characteristic and minimal toxicity profile EBRT appears to be a suitable candidate for CAO palliation. ${ }^{8}$ Therefore, in scarcity of such studies, we planned to retrospectively assess the efficacy of palliative EBRT and associated prognostic factors in MLC patients presenting with clinical symptoms or chest X-ray findings of CAO.

\section{PATIENTS and METHODS}

\section{Eligibility Criteria}

A retrospective database search was performed to identify MLC patients presenting with clinical symptoms or chest X-ray findings of CAO. To be eligible, patients had to meet the following criteria: histologically proven non-small cell- (NSCLC) or small-cell lung carcinoma (SCLC) diagnosis; age $>18$; Eastern Cooperative Oncology Group (ECOG) performance of 0-3; available pre- and post-EBRT chest X-rays, available EBRT dosimetric datasets, and no history of prior thoracic radiotherapy (RT) to the apparent CAO port. The study protocol was approved by the institutional review board before any data collection.

\section{Radiotherapy}

Patients underwent volumetric treatment planning computerized tomography (CT) scan using wing board in the treatment position. The gross tumor volume (GTV) solely included the apparent mass on computerized tomography which was judged to cause CAO. The available 18F-flourodeoxyglucose (FDG)-positron emission tomography was utilized in cases with accompanying atelectasis in order to discriminate from the tumor. According to our institutional standards for such patients the clinical target volume (CTV) was equivalent to GTV, while the planning target volume (PTV) was created by adding an isometric $1 \mathrm{~cm}$ margin to the CTV at all directions. The right, left and total lungs, heart, spinal cord (SC), esophagus and whole liver were all delineated as the organs at risk (OAR). Total doses of 8 to $40 \mathrm{~Gy}$ in 1 to 13 fractions were prescribed and 3-dimensional conformal EBRT technique was utilized in all patients. The optimal EBRT schedule was chosen by taking into account the performance status of patient, tumor size and proximity with the OAR. To be acceptable, the $95 \%$ isodose line had to cover the $100 \%$ of the PTV and maximal PTV dose was restricted to $107 \%$ of the prescribed dose. In case of using the 39-40 Gy schedules in 13 and 10 fractions, respectively, the maximum dose constraint of spinal cord was calculated utilizing the biologically equivalent dose-2 Gy (BED2= n.d. $(1+d / \alpha / \beta)$, with 36.6 Gy and 30.6 Gy maximum point doses being set for 39 and $40 \mathrm{~Gy}$, respectively. Concurrent chemotherapy was not permitted. 
Table 1. Patient baseline and treatment characteristics

\begin{tabular}{ll}
\hline Characteristics & All patients \\
\hline Median age, years (range) & 64 (46-79) \\
Gender (N;\%) & $52(72.0)$ \\
Male & $20(28.0)$ \\
Female & \\
ECOG performance (N;\%) & $36(50.0)$ \\
1 & $18(25.0)$ \\
2 & $18(25.0)$ \\
3 & \\
Histology (N;\%) & $53(73.6 .0)$ \\
NSCLC & $19(26.4 .0)$ \\
SCLC & \\
EBRT schedule (N;\%) & $7(9.8)$ \\
$1 \times 8$ Gy & $13(18.0)$ \\
$5 \times 4$ Gy & $30(41.7)$ \\
$10 \times 3$ Gy & $5(7.0)$ \\
$12 \times 3$ Gy & $13(18.0)$ \\
$13 \times 3$ Gy & $4(5.5)$ \\
$10 \times 4$ Gy & \\
\hline ECOG, eastern cooperative oncology group; NSCLC, non- \\
small cell lung carcinoma; SCLC, small-cell lung carcinoma; \\
EBRT, external beam radiotherapy; Gy, gray
\end{tabular}

\section{Response Assessment}

The obstructive symptoms and treatment related acute toxicity were assessed every week or more frequently when necessary during the treatment. Revealed from the cohorts any symptom scoring systems or patient-reported questionnaires were not utilized. Therefore, the symptomatic response was assessed subjectively and solely by depending on the patients' verbal response at each meeting with the best verbal response being the best symptomatic response date. After the treatment, patients were first monitored at monthly intervals for the first 3 months and at 3-month intervals or more frequently thereafter. The objective response was assessed by comparison of the chest X-rays which were obtained prior and following the treatment.

\section{Statistical Analysis}

The primary end-point of the present study was the radiologic CAO response rate to EBRT. The secondary end-points were survival outcomes, name- ly overall survival and median CAO-free survival which were defined as the interval between the first EBRT day and the date of death/last visit and the date of lung re-obstruction, respectively. Survival was analyzed by using the Kaplan-Meier method. In order to determine the potential impact of continuous variables on survival and $\mathrm{CAO}$ response rates, Receiver Operating Curve (ROC) was utilized to categorize patients into groups according to the defined cut-off values, if available. The survival curves of subgroups were compared by using two-sided log-rank tests. A cox proportional hazard model was utilized for analyzing the relationship between different variables and survival. All tests were two-tailed. A p-value $\leq 0.05$ was considered significant. For the assessment of the potential correlation between CAO response to EBRT and available covariates, the Spearman Analysis was utilized with related $\mathrm{P}$ (rho) values. All the delivered doses were converted to BED10 to perform more reliable comparison and analysis between the treatment schedules.

\section{RESULTS}

A total of 72 MLC patients with CAO were identified to be treated with palliative EBRT at our institution and included in this retrospective cohort analysis. Patient and treatment characteristics were as summarized in Table 1. Median age was 64 years (range: $46-79$ ) with $72 \%$ being male and $75 \%$ having ECOG 0-2. Median EBRT dose was 30 Gy (range: 8-40) which was administered in 10 fractions (range: 1-13).Treatment was relatively well tolerated with only $5(6.9 \%)$ acute grade 3 toxicities (4 pneumonitis and 1 esophagitis) and no report of late grade 3-5 toxicity.

Although 11 (19.0\%) later developed re-CAO at somewhere during the follow-up period, resolution of CAO to some degree was reported in 58 patients $(80.6 \%)$ on serial chest X-ray examinations either during or after the completion of EBRT with no notable response in remaining 14 (19.6\%). The median time to achievable maximum expansion of the obstructed lung was 23 days (range: $3-86$ ) from the initiation date of EBRT for the responders which remained durable for a median of 8.1 months $(95 \%$ CI: 3.7-12.5). Time to maximum CAO response 


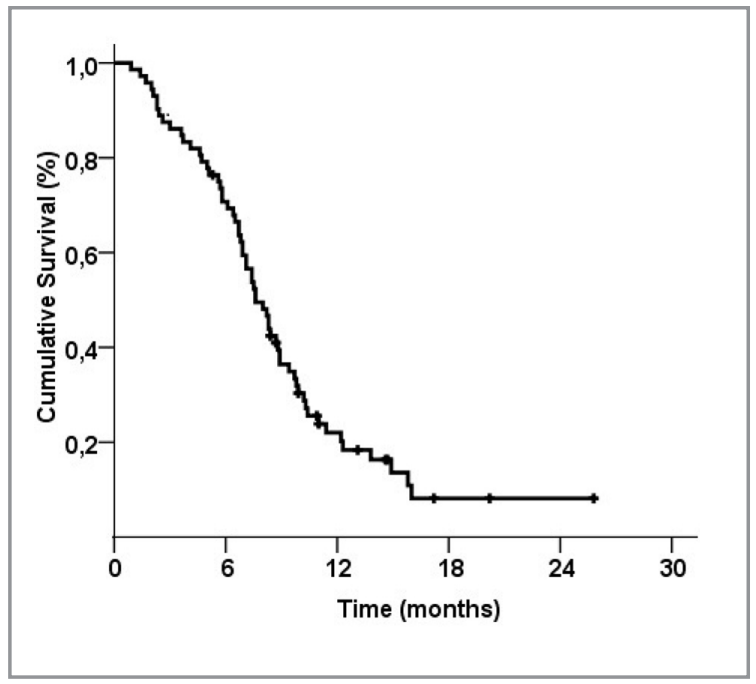

Figure 1. Overall survival in all patients

was significantly shorter in the SCLC than the NSCLC cohort ( 5 vs. 28 days; $p=0.02$ ). Similarly, maximum $\mathrm{CAO}$ response rate was also significantly higher in SCLC patients ( $89.5 \%$ vs. $77.3 \%$; $\mathrm{p}=$ 0.02).

At a median follow-up of 5.6 months (range 1.317.8), the median OS and CAO free survival were
7.6 (95\% CI: 6.5-8.7) and 7.2 months (95\% CI: 6.0-8.5) for the entire study population, respectively (Figure 1). The patients with CAO response had significantly longer median OS (8.3 vs. 2.4 months; $\mathrm{p}<0.001$ ) than the non-responders (Figure 2). For the 11 patients who experienced re-CAO had 7.4 and 5.2 months median OS and CAO-free survival times, respectively. The median ( 8.3 vs. 6.4 months; $\mathrm{p}=0.014)$ and 1-year (26.9 vs. 10.9 ; $\mathrm{p}<0.001)$ OS rates were prominently higher in patients receiving BED10 doses $\geq 39$ Gy than the lower dose counterparts (Figure 2).

In correlation analysis by Spearman test revealed that the smaller tumor size $(<5.3 \mathrm{vs} . \geq 5.3 \mathrm{~cm}$; $\mathrm{p}=$ $0.007)$ defined by ROC analysis, higher BED10 dose ( $\geq 39$ vs. $39 \mathrm{~Gy} ; \mathrm{p}<0.001$ ) and SCLC histology (SCLC vs. NSCLC; $\mathrm{p}=0.002$ ) were determined to be the factors to associate with better $\mathrm{CAO}$ response rates (Table 2). Univariate analysis assessing the OS outcomes indicated that smaller tm size $(<5.3 \mathrm{~cm} ; \mathrm{p}=0.04)$, higher EBRT dose (BED10 $\geq 39$ Gy; $<<0.001$ ) and CAO response (present; $\mathrm{p}<0.001)$ were the factors to associate with significantly superior median OS times (Table 3). However, multivariate analysis including only these
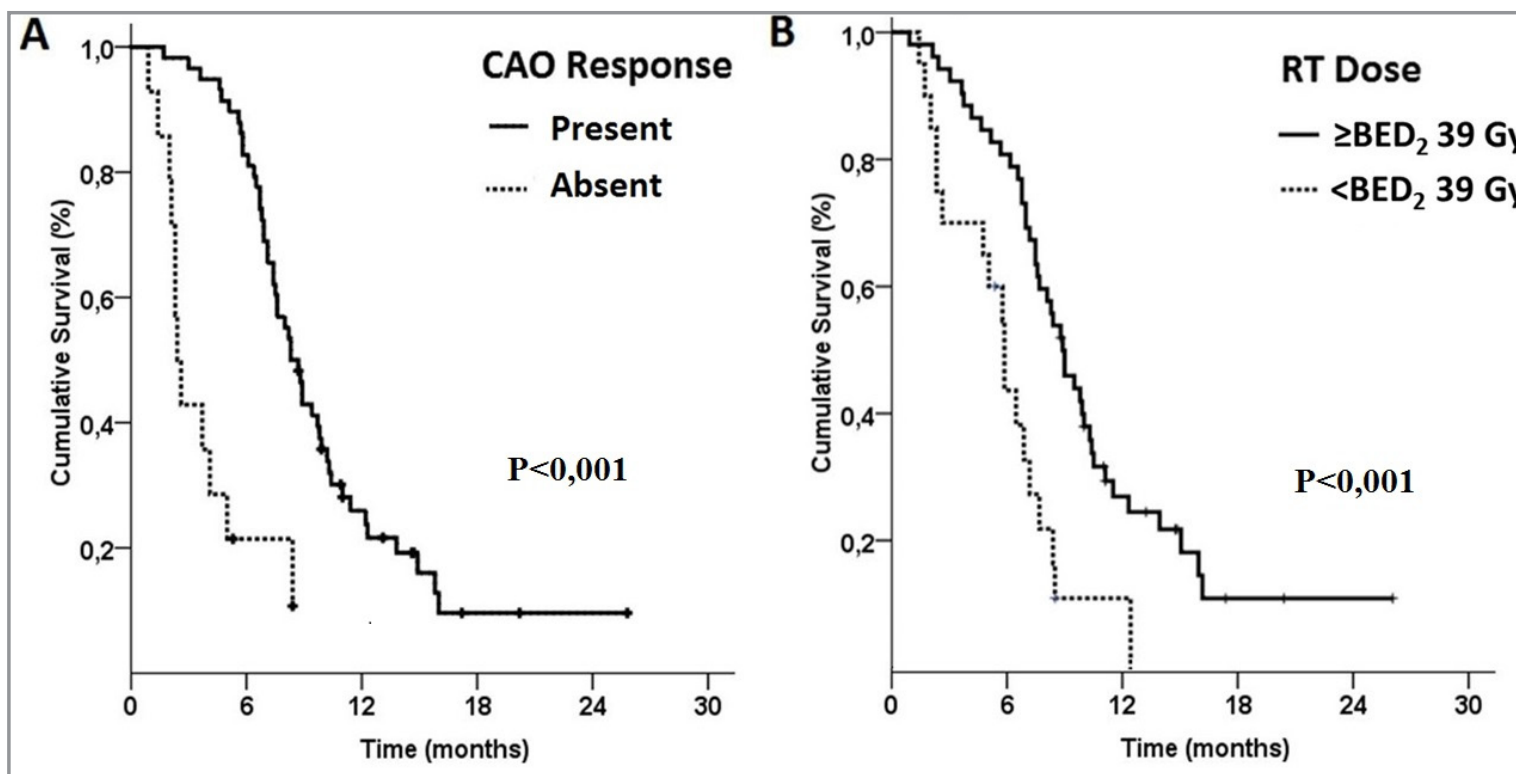

Figure 2. (A) Overall survival according to the central airway obstruction status (CAO) (B) Overall survival according to the biologically equivalent dose-10 Gy (BED10) 


\begin{tabular}{|c|c|c|c|c|}
\hline Characteristic & $\begin{array}{l}\text { Patients } \\
\text { N (\%) }\end{array}$ & $\begin{array}{l}\text { Response Rate } \\
(\%)\end{array}$ & $\begin{array}{l}\text { Correlation Coefficient } \\
\text { (Rho-value) }\end{array}$ & $p$ \\
\hline \multicolumn{5}{|l|}{ Gender } \\
\hline Male & $52(72.2)$ & 80.7 & -0.009 & 0.94 \\
\hline Female & $20(27.8)$ & 80.0 & & \\
\hline \multicolumn{5}{|l|}{ ECOG } \\
\hline $0-1$ & $36(50.0)$ & 77.0 & 0.033 & 0.78 \\
\hline 2 & $18(25.0)$ & 86.6 & & \\
\hline 3 & $18(25.0)$ & 81.3 & & \\
\hline \multicolumn{5}{|l|}{ Tumor histology } \\
\hline SCLC & $53(74.0)$ & 89.5 & 0.135 & 0.002 \\
\hline NSCLC & $19(26.0)$ & 77.3 & & \\
\hline \multicolumn{5}{|l|}{ Tumor size } \\
\hline$<5.3 \mathrm{~cm}$ & $42(58.3)$ & 92.8 & -0.355 & 0.007 \\
\hline$\geq 5.3 \mathrm{~cm}$ & $30(41.7)$ & 63.3 & & \\
\hline \multicolumn{5}{|l|}{ BED10 (Gy) } \\
\hline$\geq 39$ Gy & $20(27.7)$ & 90.3 & 0.400 & $<0.001$ \\
\hline$<39$ Gy & 52 (72.3) & 55.0 & & \\
\hline
\end{tabular}

three factors demonstrated that the tumor size lost its significant association with OS outcomes leaving the higher EBRT dose and presence of CAO response as the associators of longer OS (Figure 2).

\section{DISCUSSION}

The results of this present retrospective analysis in 72 MLC patients with CAO demonstrated that the EBRT efficiently palliated the CAO in $80.6 \%$ patients for a relatively durable time period (8.1 months) compared to their short life span (8.3 months) with only $19.0 \%$ CAO recurrences in the responders. Additional analysis revealed a significant and independent association with better CAO response and longer survival in patients with SCLC histology and EBRT dose of BED10 $\geq 39$ Gy. Present results also showed that the smaller tumor size, SCLC histology, and BED10 $\geq 39$ Gy were associated with higher $\mathrm{CAO}$ response rate, while longer survival was appeared to relate to presence of CAO response and BED10 $\geq 39$ Gy EBRT dose, respectively.
Progressive local/regional tumor growth in MLC patients may lead to significant suffering from dyspnea, hemoptysis, and cough either of which may mandate urgent palliative interventions such as stent placement, ELA, and/or PDT. ${ }^{13,14}$ Obviously, these invasive treatment modalities are satisfactorily effective in terms of providing rapid palliation in patients with CAO. However, to be applicable, first the tumor should allow the installation of the stent which may be quite difficult for endobronchial tumors obstructing the lumen near totally. Moreover, stent migration and/or obstruction are additional potential problems to be overcome that may either limit their frequent usage or may indicate use of further palliative interventions. Similarly, EBB is another invasive technique with favorable palliation outcomes for CAO. However, great caution is needed for interpretation of the EBB studies as most eligible patients had intrabronchial small tumors without extrinsic components. Alike with the aforementioned techniques EBB also suffers from a variety of notable complications including the esophageal-bronchial fistula, 
International Journal of Hematology and Oncology

\begin{tabular}{|c|c|c|c|c|}
\hline Characteristic & $\begin{array}{l}\text { Patients } \\
\text { N (\%) }\end{array}$ & $\begin{array}{l}\text { Median Survival } \\
\text { (months) }\end{array}$ & $\begin{array}{l}\text { Univariate } \\
\text { p-value }\end{array}$ & $\begin{array}{l}\text { Multivariate } \\
\text { p-value }\end{array}$ \\
\hline \multicolumn{5}{|l|}{ Gender } \\
\hline Male & 52 (72.2) & 7.4 & 0.13 & - \\
\hline Female & $20(27.8)$ & 9.4 & & \\
\hline \multicolumn{5}{|l|}{ ECOG } \\
\hline $0-1$ & $36(50)$ & 8.0 & 0.48 & - \\
\hline 2 & $18(25)$ & 7.6 & & \\
\hline 3 & $18(25)$ & 6.7 & & \\
\hline \multicolumn{5}{|l|}{ Histology } \\
\hline NSCLC & $53(74)$ & 7.3 & 0.69 & - \\
\hline SCLC & $19(26)$ & 8.6 & & \\
\hline \multicolumn{5}{|l|}{ Tumor size } \\
\hline$<5.3 \mathrm{~cm}$ & $42(58.3)$ & 8.3 & 0.04 & 0.37 \\
\hline$\geq 5.3 \mathrm{~cm}$ & $30(41.7)$ & 6.8 & & \\
\hline \multicolumn{5}{|l|}{ BED10 (Gy) } \\
\hline$<39$ Gy & $20(27.7)$ & 5.8 & $<0.001$ & 0.008 \\
\hline$\geq 39$ Gy & 52 (72.3) & 8.8 & & \\
\hline \multicolumn{5}{|l|}{ CAO response } \\
\hline Present & 58 (80.5) & 8.3 & $<0.001$ & $<0.001$ \\
\hline Absent & 14 (19.5) & 2.4 & & \\
\hline
\end{tabular}

bronchial wall necrosis, and/or massive hemoptysis. ${ }^{8,15-18}$ Considering these facts, the noninvasive EBRT with its minimal toxicity profile may be a rational treatment choice in these highly fragile patients with tumors of any size independent of their relation with the bronchial lumen.

One important finding of the present study was the excellent response rate of CAO to EBRT (80.6\%) with relatively long CAO-free duration (8.1 months) compared to the median OS of 8.3 months achieved in the responder patients. This observation clearly underlies the long lasting efficacy of EBRT in management of CAO. Considering the efficacy of EBRT in management of CAO, in a study by Lee et al. including 95 patients who were treated with 8 to 45 Gy (1 to 15 fractions) EBRT due to obstructive lung masses of NSCLC $(n=59)$ or SCLC $(n=36)$ were analyzed. ${ }^{19}$ The reported $79 \%$ CAO improvement with EBRT by Lee et al. is almost identical to our $80.6 \%$ response rate noted here. The present results are additionally confirmed by the reported $65-77 \% \mathrm{CAO}$ improvement rate noted in the large Fairchild meta-analysis that included 13 randomized studies and 3473 patients. ${ }^{20}$ Apart from this finding, we additionally demonstrated that even in the 11 patients (19\%) who experienced re-obstruction after EBRT had a CAO-free interval of 5.2 months, corresponding to the $70 \%$ of calculated remaining life span (7.4 months) in these patients. This additional observation may serve important considering the detrimental effects of CAO on patients' quality of life and its appreciable improvement with EBRT.

In spite of the well-recognized differential efficacy of EBRT on local tumor control in non-metastatic SCLC and NSCLC patients ${ }^{21,22}$, to our best knowledge, the tumor histology (NSCLC vs. SCLC) related CAO-response differences have been rarely addressed. ${ }^{19}$ For instance, in their aforementioned study Lee et al. could not demonstrate any difference between the CAO responses of NSCLC and SCLC patients $(78.0 \%$ vs. $80.6 \% ; p=0.76)$ after 
EBRT. ${ }^{19}$ In this respect our results are in stark contrast with Lee's outcomes as SCLC patients appeared to demonstrate better $\mathrm{CAO}$ response to EBRT (89.5\% vs. $77.3 \%$; $\mathrm{p}=0.002$ ). Although it is difficult to assign this distinction to exact causes, yet it is reasonable to anticipate that the striking higher radiosensitivity of SCLC to RT than NSCLC may have played the major role on this difference. ${ }^{23}$ This anticipation is supported by the RT doses utilized in the landmark SCLC and NSCLC studies for non-metastatic LC patients [24-26], which is 45 Gy for SCLC [26] and 60-66 Gy for NSCLC. ${ }^{24,25}$, respectively. Similarly, align with the related literature the faster maximum CAO-response observed here in SCLC patients than their NSCLC counterparts ( 5 vs. 28 days; $p=0.02$ ) is also highly probable to associate with the higher relative radiosensitivity of the SCLC. ${ }^{22}$

In addition to better symptom improvement, high dose RT rather than the conventional palliative dose schedules may also prove survival benefit in patients presenting with CAO. ${ }^{19,20,27}$ In line with this evident dose-response relationship [20], our analysis demonstrated that both the actual CAO resolution- (90.3 vs. $55 \%$; $\mathrm{p}<0.01)$ and median(8.3 vs. 6.4 months; $\mathrm{P}=0.014$ ) and 1 -year (26.9 vs. $10.9 \%, \mathrm{p}<0.001)$ OS rates were significantly superior with BED10 doses $\geq 39$ Gy than the lower dose counterparts. This observation is strengthened with a recent study by Tanaka et al. ${ }^{27}$ and a relatively older meta-analysis by Fairchild et al. ${ }^{20}$ In both analyses the authors reported a dose benefit of EBRT was also supported by and a study of which addressed to 35 Gy10 as a threshold value for prolonged survival $(27 \%$ vs. $22 \%$ at 1 -year; $\mathrm{p}=0.002$ ) and favorable symptom control, respectively. Therefore, altogether these results suggest the use of total dose and fractionation achieving for better results.

In addition to the tumor histology and EBRT dose, the tumor size is another suggested factor to alter CAO response rates after both EBB and EBRT., 2,19,28 Based on the available literature, it may be rational to propose that CAO caused by smaller tumors may response to a prescribed EBRT dose than larger ones, as it is evident from LC literature. ${ }^{29}$ In this respect, tumor size of $<6 \mathrm{~cm}$ was reported to associate with better CAO-free ${ }^{19}$ and local control rates [30]. Similarly in our present study, the ROC analysis identified that patients with $<5.3 \mathrm{~cm}$ tumor size as the cut off for better RT response (92.8 vs. $63.3 \% ; \mathrm{p}=0.007$ ) and median CAO-free interval ( 8.3 vs. 5.7 months; $\mathrm{p}=0.012$ ), this could not translate into a significant covariate affecting the outcomes in the multivariate analysis $(\mathrm{p}=$ 0.41). Therefore, the outcomes of Tanaka's study and the one presented here suggest a potential role for tumor size in prediction of CAO-response after EBRT, which deserve to be addressed in larger studies to conclude in a more reliable manner.

The present study has several drawbacks. First, as common to any single institutional small retrospective study, unpredictable biases may have influenced our results. Second, absence of the patient-reported objective questionnaire forms and functional examinations including respiratory function tests or bronchoscopic evaluations limit our ability to conclude more reliably. Instead, we utilized serial chest X-rays, patients' self-assessments, and physician in charge's judgement based on the physical examinations which are prone to biasing effects as they are more or less subjective evaluation tools. However, although we recognize the handicaps of subjective assessments, it should be remembered that use of more objective tools such as the respiratory function tests or CT scanning may be extremely difficult or even impossible in at least some patients with severe dyspnea. Fourth, use of different EBRT dose fractionation schedules in discretion of the physician in charge by considering the patients' general health status may have favored one group over the other, particularly the high dose group. In this respect, the dose response relationship in different performance status levels and its translation to survival outcomes in such patients deserves to be addressed in future studies with larger cohorts. And fifth, use of various chemotherapeutics and/or targeted agents in some patients may have potentially altered the outcomes reported here. Therefore, respecting these limitations, we believe that our results should better be interpreted with caution considering the above mentioned factors. 


\section{CONCLUSION}

The outcomes of current retrospective analysis demonstrated efficacy of the EBRT in palliation of the NSCLC or SCLC originated CAO for almost the rest of their remaining life span in responders, with only $19.0 \%$ CAO recurrences. Additionally we identified the higher EBRT dose (BED10 $\geq 39$ Gy), smaller tumor size $(<5.3 \mathrm{~cm})$ and SCLC histology as the factors to associate with better CAO response after the noninvasive EBRT.

\section{REFERENCES}

1. Gompelmann D, Eberhardt R, Herth FJ. Advanced malignant lung disease: what the specialist can offer. Respiration 82: 111-123, 2011.

2. Aumont-le Guilcher M, Prevost B, Sunyach MP, et al. Highdose-rate brachytherapy for non-small-cell lung carcinoma: a retrospective study of 226 patients. Int J Radiat Oncol Biol Phys 79: 1112-1116, 2011

3. Ettinger DS, Akerley W, Borghaei $\mathrm{H}$, et al. Non-small cell lung cancer. J Natl Compr Canc Netw 10: 1236-1271, 2012.

4. Rodrigues G, Macbeth F, Burmeister B, et al. Consensus statement on palliative lung radiotherapy: third international consensus workshop on palliative radiotherapy and symptom control. Clin Lung Cancer 13: 1-5, 2012.

5. Adamietz IA. Radiotherapy. Front Radiat Ther Oncol 42: 164$172,2010$.

6. Wahidi MM, Herth FJ, Ernst A. State of the art: interventional pulmonology. Chest 131: 261-74, 2007.

7. Javle M, Ailawadhi S, Yang GY, et al. Palliation of malignant dysphagia in esophageal cancer: a literature-based review. J Support Oncol 4: 365-373, 2006.

8. Klopp AH, Eapen GA, Komaki RR. Endobronchial brachytherapy: an effective option for palliation of malignant bronchial obstruction. Clin Lung Cancer 8: 203-207, 2006.

9. Alazemi S, Lunn W, Majid A, et al. Outcomes, health-care resources use, and costs of endoscopic removal of metallic airway stents. Chest 138: 350-356, 2010.

10. Ost DE, Shah AM, Lei $X$, et al. Respiratory infections increase the risk of granulation tissue formation following airway stenting in patients with malignant airway obstruction. Chest 141: 1473-1481, 2012.

11. Chung FT, Chen HC, Chou CL, et al. An outcome analysis of self-expandable metallic stents in central airway obstruction: a cohort study. J Cardiothorac Surg 6: 46, 2011.

12. Wood DE. Airway stenting. Chest Surg Clin N Am 11: 841860, 2001.
13. Moghissi K, Dixon K, Stringer M, et al. The place of bronchoscopic photodynamic therapy in advanced unresectable lung cancer: experience of 100 cases. Eur J Cardiothorac Surg 15: 1-6, 1999

14. Stephens KE, Jr., Wood DE. Bronchoscopic management of central airway obstruction. J Thorac Cardiovasc Surg 119: 289-296, 2000.

15. Escobar-Sacristan JA, Granda-Orive Jl, Gutierrez Jimenez T, Det al. Endobronchial brachytherapy in the treatment of malignant lung tumours. Eur Respir J 24: 348-352, 2004.

16. Gollins SW, Burt PA, Barber PV, Stout R. High dose rate intraluminal radiotherapy for carcinoma of the bronchus: outcome of treatment of 406 patients. Radiother Oncol 33: 31 40, 1994.

17. Stout R, Barber $P$, Burt $P$, et al. Clinical and quality of life outcomes in the first United Kingdom randomized trial of endobronchial brachytherapy (intraluminal radiotherapy) vs. external beam radiotherapy in the palliative treatment of inoperable non-small cell lung cancer. Radiother Oncol 56: 323732,2000

18. Speiser BL, Spratling L. Remote afterloading brachytherapy for the local control of endobronchial carcinoma. Int J Radiat Oncol Biol Phys 25: 579-587, 1993.

19. Lee JW, Lee JH, Kim HK, et al. The efficacy of external beam radiotherapy for airway obstruction in lung cancer patients. Cancer Res Treat 47: 189-196, 2015.

20. Fairchild A, Harris K, Barnes E, et al. Palliative thoracic radiotherapy for lung cancer: a systematic review. J Clin Oncol 26: 4001-411, 2008.

21. Stinchcombe TE, Gore EM. Limited-stage small cell lung cancer: current chemoradiotherapy treatment paradigms. Oncologist 15: 187-195, 2010.

22. Carney DN, Mitchell JB, Kinsella TJ. In vitro radiation and chemotherapy sensitivity of established cell lines of human small cell lung cancer and its large cell morphological variants. Cancer Res 43: 2806-2811, 1983.

23. McGarry RC. Extensive-Stage Small Cell Lung Cancer: Is Consolidative Thoracic Radiation Therapy Really a New Standard of Care? Int J Radiat Oncol Biol Phys 93: 10-12, 2015.

24. Curran WJ, Jr., Paulus R, et al. Sequential vs. concurrent chemoradiation for stage III non-small cell lung cancer: randomized phase III trial RTOG 9410. J Natl Cancer Inst 103: 1452-1460, 2011.

25. Furuse K, Fukuoka M, Kawahara M, et al. Phase III study of concurrent versus sequential thoracic radiotherapy in combination with mitomycin, vindesine, and cisplatin in unresectable stage III non-small-cell lung cancer. J Clin Oncol 17: 2692-2699, 1999

26. Turrisi AT 3rd, Kim K, Blum R, et al. Twice-daily compared with once-daily thoracic radiotherapy in limited small-cell lung cancer treated concurrently with cisplatin and etoposide. $\mathrm{N}$ Engl J Med 340: 265-271, 1999. 
27. Tanaka H, Hayashi S, Ohtakara K, Hoshi H. Palliative radiotherapy for patients with tracheobronchial and esophageal compression due to intrathoracic malignant tumors. Asia Pac J Clin Oncol 8(4): e82-8, 2012.

28. Harms W, Schraube P, Becker H, et al. Effect and toxicity of endoluminal high-dose-rate (HDR) brachytherapy in centrally located tumors of the upper respiratory tract. Strahlenther Onkol 176: 60-66, 2000.

29. Werner-Wasik M, Swann RS, Bradley J, et al. Increasing tumor volume is predictive of poor overall and progression-free survival: secondary analysis of the Radiation Therapy Oncology Group 93-11 phase I-II radiation dose-escalation study in patients with inoperable non-small-cell lung cancer. Int $\mathrm{J}$ Radiat Oncol Biol Phys 70: 385-390, 2008.

30. Willner J, Baier K, Caragiani E, et al. Dose, volume, and tumor control prediction in primary radiotherapy of non-smallcell lung cancer. Int J Radiat Oncol Biol Phys 52: 382-389, 2002.

\section{Correspondence}

Dr. Yurday ÖZDEMIR

Baskent Üniversitesi Adana Tedavi ve Arastrima Merkezi

Radyasyon Onkolojisi Bölümü

01120, ADANA /TURKEY.

Tel: (+90-505) 5942169

e-mail: yurdayozdemir@gmail.com 